\title{
Improving Aviation Safety in Indonesia: How Many More Accidents?
}

\author{
Ridha Aditya Nugraha \\ German Aviation Research Society, Berlin, Germany; \\ Air Power Centre of Indonesia, Jakarta, Indonesia. \\ E-mail: r.a.nugraha@umail.leidenuniv.nl \\ Submitted: Sep 15, 2016; Reviewed: Nov 21, 2016; Accepted: Dec 4, 2016

\begin{abstract}
Numerous and consecutive aircraft accidents combined with a consistent failure to meet international safety standards in Indonesia, namely from the International Civil Aviation Organization and the European Aviation Safety Agency have proven a nightmare for the country's aviation safety reputation. There is an urgent need for bureaucracy reform, harmonization of legislation, and especially ensuring legal enforcement, to bring Indonesian aviation safety back to world standards. The Indonesian Aviation Law of 2009 was enacted to reform the situation in Indonesia. The law has become the ground for drafting legal framework under decrees of the Minister of Transportation, which have allowed the government to perform follow-up actions such as establishing a single air navigation service provider and guaranteeing the independency of the Indonesian National Transportation Safety Committee. A comparison with Thailand is made to enrich the perspective. Finally, foreign aviation entities have a role to assist states, in this case Indonesia, in improving its aviation safety, considering the global nature of air travel.
\end{abstract}

Keywords: Aircraft Accident; Aviation Safety; Legal Enforcement

DOI: 10.20956/halrev.v2i3.321

\section{INTRODUCTION}

Sadly, aircraft accidents continue to occur on a regular basis in Indonesia. It seems unstoppable. While aircraft accidents from the neighbouring ASEAN countries such as the Philippines (which is also an archipelagic country), Thailand, Malaysia, and Singapore remain a comparatively rare occurrence, it seems that aviation in Indonesia has become synonymous with accidents.

As a consequence, currently the world, through the perspective of International Civil Aviation Organization (ICAO), has seen flying in Indonesia as abnormally risky.
Through its audit in 2007, followed by the Federal Aviation Administration of the United States (FAA) and the European Aviation Safety Agency (EASA), a conclusion has been made that Indonesian aviation safety is below international standards. A ban or 'sanction' towards Indonesian aviation is the next potential step. A reprieve however came in August 2016 when the FAA increased Indonesia's status back to level one - or the highest standard.

Substandard aviation safety in Indonesia occurs due domestic obstacles to providing proper legal enforcement, bureaucratic 
reform, and sufficient human resources that are the result of a legal framework that has not kept pace with the rapid development of the Indonesian aviation business. Thus many Indonesian airlines may be fully aware that they are not operating in the safest possible manner, but currently lack sufficient governmental guidance and means to rectify the situation. This is a gap that must be solved immediately for the sake of all airline passengers' lives.

The situation has spurred the Indonesian government to take improving aviation safety more seriously through consecutive and well planned domestic action and international cooperation. Without question the Indonesian authorities face a hard task to show the world that the safety level is already improved after the Indonesia AirAsia QZ8501 tragedy, which was compounded within a half year with the fatal Trigana Air Service Flight 257 and Aviastar MV7503 accidents in 2015; and also numerous 'minor' accidents like skidding.

In order to provide a comprehensive analysis, this article shall begin with describing the history of aircraft accidents in Indonesia within the last decade and the country's current aviation safety level according to international standards. Furthermore, the government efforts to improve aviation safety level since 2007, namely since Indonesia began to be banned, through the implementation of new legal framework shall be described; along with current international cooperation. At the end, the Indonesian efforts improving aviation safety could become a lesson for other ASEAN member states, in particular Thailand who currently shares the same situation.

\section{ANALYSIS AND DISCUSSION}

Aircraft Accidents in Indonesia within the Last Decade

Numerous consecutive tragedies in the Indonesian aviation world occurred within the past years. Just recently, in April 2016, a Boeing 737-800 Batik Air collided during take-off on the runway with an ATR 42-600 operated by TransNusa Air Services at Jakarta Halim Perdana Kusuma Airport. According to a Batik Air press release shortly after the incident, its aircraft had been cleared for take off, but collided with TransNusa's aircraft that was being towed by a tug. ${ }^{1}$ Fortunately, there were no injuries or fatalities within with this accident, 'only' damage to both aircraft.

In December 2014, Indonesia AirAsia Flight QZ8501 from Surabaya to Singapore crashed into the Java Sea, killing all 162 people on board. Bad weather in the area was first speculated as the main cause of the accident for the unfortunate Airbus A320-200. During a press conference held by the Indonesian Minister of Transportation a few days later, it was announced that the aircraft climbed at a speed beyond normal before it stalled. ${ }^{2}$ A year later, the National Transportation Safety Committee of Indonesia (NTSC) released the final investigation

\footnotetext{
Aviation Safety Network (2016). Accident Description Available from: http://aviation-safety.net/database/ record.php?id=20160404-0 [Accessed August 18, 2016].

Kompas.com (2015). Menhub Jonan Ungkap Pesawat AirAsia QZ8501 Alami "Stall". Available from: http:// nasional.kompas.com/read/2015/01/20/20192001/ Menhub.Jonan.Ungkap.Pesawat.AirAsia.QZ8501. Alami.Stall [Accessed August 18, 2016].
} 
report which concluded that the cracking of one aircraft components followed by incorrect flight crew action handling the situation were the contributing factors to the crash. ${ }^{3}$

Another two aircraft accidents also occurred in 2015. These accidents were Trigana Air Service Flight 257, crashed in Papua, followed by Aviastar MV7503 that crashed in Sulawesi, where both happened 'only' within two months of each other in August and October 2015. Unfortunately, there were no survivors from these accidents thus further increasing the death toll within the recent history of Indonesian aviation. Unlike AirAsia QZ8501, both flights served domestic routes and could be classified as pioneer flights. An additional accident happened on a joy flight where a Sukhoi RRJ-95B crashed into Mount Salak in May 2012 when they were introducing the new aircraft. Again, no survivor in this crash where forty-five lives were lost.

These fatal accidents reminded the public of the Adam Air KI-574 accident in 2007 which had also caused concern of the aviation safety level in this country. A Boeing 737-400 lost contact near Majene and is believed to have crashed into the sea, killing all ninety-six people on board. Unfortunately, it was Singapore rather than Indonesia that first noticed the aircraft disappearance due their advanced navigation systems. ${ }^{4}$ Still within the same year, Garuda Indonesia GA200 which served Jakarta-Yogyakarta route crashed while landing at Adisutjipto Air-

The National Transportation Safety Committee of Indonesia. (2015). Aircraft Accident Investigation Report No. KNKT.14.12.29.04, p. 13.

4 Chappy Hakim. (2009). Cat Rambut Orang Yahudi. Jakarta: Kompas, p. 77. port, killing twenty-two people on board. ${ }^{5}$ Undoubtedly these aircraft accidents have raised a serious question of the level of safety within the current Indonesian aviation world that must be improved as soon as possible.

Following the ASEAN Open Skies agreement which came into effect on 1 January 2015, more scheduled commercial flights between member states will be held. In order to maximize the commercial expansion of Indonesian airlines within this region, such as Garuda Indonesia, Citilink, Lion Air, and Sriwijaya Air, safety issues must be made as a main priority to be solved. Failure to do so means in the ASEAN Open Skies Indonesian airlines and their supporting industries will be merely spectators, as travellers choose other more established member states' airlines with much better safety records when traveling to and from Indonesia. Serious work must be done and quickly by the Indonesian government if the aviation safety level within this country is to be recognized on par with other countries.

\section{Today's Indonesia's Position in the Avia-} tion Safety World: Further and Further

\section{Behind}

Considering the number of accidents in recent years, it is not surprising if almost all Indonesian airlines have been banned from flying to and through European Union (EU) airspace since July 2007. ${ }^{6}$ The EU ban was

\footnotetext{
Hukumonline (2007). KNKT: Kecelakaan Garuda di Yogyakarta Murni Human Error. Available from: http:// www.hukumonline.com/berita/baca/hol17842/knktkecelakaan-garuda-di-yogyakarta-murni-ihuman-errori [Accessed August 19, 2016].

6 Four Indonesian airlines, namely Garuda Indonesia, Airfast Indonesia, Ekspres Transportasi Antarbenua, and Indonesia AirAsia, are excluded when EU lifted their ban under special conditions in 2010. Just recently in 2016, three other airlines, namely Batik Air, Citilink,
} 
also a follow-up action after the FAA downgraded Indonesia's rating from category one to category two in April $2007 ;^{7}$ which was only restored to the highest safety level again in August 2016. This action caused some talk of whether politics played a role during that period, such as the worsening relationship between the EU and Indonesia (ASEAN) and competition between Boeing and Airbus. ${ }^{8}$ In 2013 Indonesia's Lion Air 'responded' by ordering 234 Airbus A320 aircraft, breaking a world record. ${ }^{9}$ Some have speculated this was done to win favour from the EU and thus ultimately ease or lift the ban. However, both authorities have only corroborated the ICAO findings that the Indonesian authorities did not meet the standard for ensuring an adequate level of aviation safety.

It is ultimately 'fortunate' that EU, and once the FAA, has banned Indonesia; as it is important for the sake of the airline passengers' lives whatever their nationality considering aviation is a global issue. Due to these sanctions Garuda Indonesia lost potential international market share and face as a flag carrier that could not fly to Europe in between 2007-2009. However, this ban was needed to open the Indonesian Directorate General of Civil Aviation's (DGCA) eyes that they were not doing enough to protect passengers' lives. The DGCA has been too afraid to sanction the airlines who do

and Lion Air, are excluded from the EU black list.

7 Chappy Hakim. (2014). Believe It or Not: Dunia Penerbangan Indonesia - Terbang Aman dan Nyaman walau Banyak Masalah. Jakarta: Kompas, p. 60.

8 Chappy Hakim. (2009), Op.cit., p. 62.

9 Airbus (2013). Lion Air Orders 234 A320 Family Aircraft. Available from: http://www.airbus.com/ presscentre/pressreleases/press-release-detail/detail/ lion-air-orders-234-a320-family-aircraft/ [Accessed on August 24, 2016]. not comply with regulations; and also, too easy in issuing operating licenses to new airlines. ${ }^{10}$

Currently the ICAO has a method to assess each country's aviation safety level. It is the so-called Universal Safety Oversight Audit Program Continuous Monitoring Approach (USOAP-CMA) which was launched in 1999 in response to widespread concerns about the adequacy of aviation safety oversight around the world. ${ }^{11}$ There are eight components that come into consideration for the scoring system which are legislation, organization, licensing, operations, airworthiness, accident investigation, air navigation services, and aerodromes.

In May 2014, Indonesia could 'only' obtain an average score of 39.05 (out of 100); ${ }^{12}$ which increased slightly in March

10 Chappy Hakim. (2009), Op.cit., p. 56.

11 USOAP audits focus on a state's capability in providing safety oversight by assessing whether the State has effectively and consistently implemented the critical elements of a safety oversight system and determining the State's level of implementation of ICAO's safety-related Standards and Recommended Practices (SARPs) and associated procedures and guidance material. In September 2007, the 36th Session of the Assembly adopted Resolution A36-4 directing the Council to examine different options for the continuation of the USOAP beyond 2010, including the feasibility of applying a new approach based on the concept of continuous monitoring and incorporating the analysis of safety risk factors. The systematic and more proactive conduct of monitoring activities in the new USOAP Continuous Monitoring Approach (CMA) would make a more effective and efficient use of ICAO resources and reduce the burden on States caused by repetitive audits. USOAP-CMA would also increase the role of other ICAO bureau and the regional offices, include States' commitment to the programme by providing ICAO with relevant safety information and expand and amend ICAO's agreements for the sharing of confidential safety information with international entities and organizations. As of January 2013, USOAP-CMA is already fully launched. See ICAO. USOAP Continuous Monitoring Approach. Available from: http://www.icao.int/safety/CMAForum/Pages/ default.aspx [Accessed August 20, 2016].

12 Audit period was between 5 to 14 May 2014. See ICAO. Safety Audit Information. Available from: http://www. icao.int/safety/Pages/USOAP-Results.aspx [Accessed 
2015, with an average score of $45.09 \cdot ;^{13}$ and finally increased to 47.23 per-September 2016. ${ }^{14}$ However, the score was not sufficient considering the minimum score to be considered a 'pass' is a 60 . The world however will be looking as to whether this country can improve this score in 2016.

As a comparison with the situation among other ASEAN member states, Indonesia could only compete with the Philippines, as another archipelagic state, in terms of air navigation services and aerodromes, thus losing in all other aspects (see Table 1). Indonesia also lagged behind Malaysia and Singapore. Speaking of the latter, its level of aviation safety is overwhelming, not only to compared to Indonesia but also to the world, where their average score reaches more than 96 (of 100), with a perfect score at three aspects. With an almost perfect score (98.45) for providing "Air Navigation Services", no wonder if Singapore has made a strong stance for providing air navigation service above some parts of the Indonesian airspace, namely the Riau and Natuna islands (or also known as the Natuna FIR), delaying its transfer back to the Indonesian authority claiming a aviation safety basis.

This is a fact that must be accepted, where currently Indonesia is being left behind the other ASEAN countries, finding itself at the bottom third of the ranking. A simply conclusion can be made that the Indonesian DGCA has not done well enough

March 15, 2016].

13 Direktorat Jenderal Perhubungan Udara (2015). Diharapkan Bisa Naikkan Nilai Skor Menjadi 72. Available from: http://hubud.dephub.go.id/?id/news/ detail/2466 [Accessed August 24, 2016].

14 ICAO. Safety Audit Information. Available from: http://www.icao.int/safety/Pages/USOAP-Results.aspx [Accessed September 12, 2016]. to ensure aviation safety within the country. As a result, Indonesian aviation currently has one of the most expensive insurance premiums in the world. ${ }^{15}$

\section{Comparison with Thailand: Similar chal- lenges}

At the moment, Thailand scores below the global average. It is interesting to see how Thailand's USOAP-CMA score fell in all of aspects just within a half year, namely from March to October 2015. Following this situation, the FAA downgraded Thailand's aviation safety rating to category two in December $2015 ;{ }^{16}$ due to lack of laws or regulations to properly oversee its air carriers in accordance with minimum international standards. ${ }^{17}$ Prior to this downgrade, the ICAO had "red flagged" Thailand over significant safety concerns within the country's aviation sector in the same year. ${ }^{18}$ These bans mean a potential for Thai-registered airlines, like most Indonesian airlines, to be restricted from flying to some extend countries with high aviation safety levels in Asia, such as Japan and South Korea.

Currently, existing scheduled flights to Japan and South Korea operated by Thailand registered-airlines are still allowed,

15 Chappy Hakim. (2010). Berdaulat di Udara. Jakarta: Kompas, p. 201.

16 CNN (2015). FAA Downgrades Thailand Over Aviation Safety Concerns. Available from: http://edition.cnn. com/2015/12/02/aviation/thailand-aviation-safety-faa/ [Accessed August 28, 2016].

17 The Telegraph (2015). Thailand Airlines Downgraded Over Safety Concerns. Available from: http://www. telegraph.co.uk/travel/destinations/asia/thailand/ articles/Thailands-airlines-downgraded-over-safetyconcerns/ [Accessed August 27, 2016].

18 CNN (2015). Thailand 'Red-Flagged' for Aviation Safety Concerns. Available from: http://edition. cnn.com/2015/06/19/travel/thailand-aviation-safety [Accessed August 27, 2016]. 
Table 1. A comparison of USOAP-CMA scores in five ASEAN member states.

\begin{tabular}{lcccccc}
\hline \multirow{2}{*}{\multicolumn{1}{c}{ Aspects }} & \multicolumn{7}{c}{ ASEAN Countries } \\
\cline { 2 - 6 } \multicolumn{1}{c}{ Global Average } & Indonesia & Thailand & Singapore & Malaysia & Philippines \\
\hline Legislation & 68.60 & 59.09 & 27.27 & 100 & 83.33 & 90.91 \\
Organization & 66.17 & 26.67 & 7.69 & 100 & 66.67 & 81.82 \\
Licensing & 72.15 & 36.56 & 35.87 & 96.30 & 77.38 & 80.77 \\
Operations & 66.81 & 46.38 & 10.71 & 100 & 84.13 & 83.06 \\
Airworthiness & 75.03 & 68.78 & 62.60 & 98.11 & 84.62 & 88.29 \\
Accident Investigation & 54.20 & 32.41 & 41.67 & 96.84 & 33.33 & 44.33 \\
Air Navigation Services & 58.08 & 56.25 & 29.81 & 98.45 & 91.79 & 35.23 \\
Aerodromes & 56.70 & 51.70 & 32.69 & 99.32 & 93.08 & 38.13 \\
\hline
\end{tabular}

Source: ICAO - compiled based on different audit period: i. Indonesia (2016); ii. Thailand (March 2015); iii. Singapore (August 2010); iv. Malaysia (June-July 2005); and v. the Philippines (February 2013).

Tabel 2. Comparison of USOAP-CMA score for Indonesia and Thailand in 2015 and 2016.

\begin{tabular}{lcccc}
\hline \multirow{2}{*}{\multicolumn{1}{c}{ Aspects }} & \multicolumn{2}{c}{ Indonesia } & \multicolumn{2}{c}{ Thailand } \\
\cline { 2 - 5 } & March (2015) & September (2016) & March (2015) & September (2016) \\
\hline Legislation & 33.33 & 59.09 & 76.19 & 27.27 \\
Organization & 17.65 & 26.67 & 46.15 & 7.69 \\
Licensing & 33.70 & 36.56 & 88.46 & 35.87 \\
Operations & 38.13 & 46.38 & 69.84 & 10.71 \\
Airworthiness & 61.05 & 68.78 & 94.50 & 62.60 \\
Accident Investigation & 31.48 & 32.41 & 61.62 & 41.67 \\
Air Navigation Services & 50.94 & 56.25 & 87.00 & 29.81 \\
Aerodromes & 44.59 & 51.70 & 74.17 & 32.69 \\
\hline
\end{tabular}

Source: ICAO - data per-26 April 2015 and 10 September 2016.

but adding new route is forbidden. ${ }^{19}$ A relief came for Thai airlines when EASA spared them a ban from European skies at the end of 2015, saying instead it will assist the country in upgrading its aviation safety. ${ }^{20}$

The latest scores (September 2016) in Table 2 indicate both countries faced serious problems with bureaucracy (organization), keeping legal framework up-todate (legislation and operations), and most importantly, ensuring legal implementation

19 The Japan Times. Japan Temporarily Lifts Flight Ban Imposed on Thai Airlines Over Safety Issues. Available from: http://www.japantimes.co.jp/news/2015/04/02/ national/japan-temporarily-lift-thai-airlines-charterflight-ban-imposed-safety-issues/\#.V9cPN5N96Ax [Accessed August 28, 2016].

20 Bangkok Post (2015). Thai Airlines Pass EU Safety Test. Available from: http://www.bangkokpost.com/ learning/work/791829/thai-airlines-pass-eu-safety-test [Accessed August 28, 2016]. and enforcement. Legal enforcement or implementation is undoubtedly an issue considering the unfortunate habit of officials reporting only 'pleasant' information; a condition deemed to be caused by corruption, collusion, and nepotism which are currently being fought in both countries.

Currently Thailand and Indonesia are in a similar situation, where their aviation safety is doubted by the world. Thailand's reputation could be described, more or less, as from hero to zero in ASEAN. A political will with serious steps must be taken to ensure that the aviation industry continues to develop within the country. Thailand's prime minister has ordered a swift overhaul of his country's aviation system in response 
to the FAA's decision downgrading the country aviation safety rating. ${ }^{21}$ Hopefully a stable political situation can occur within the country, so focus and energy could be shifted to improve aviation safety.

There is always a light of hope for Thailand in the form of the Philippines, which returned to FAA category one last April 2015 after being downgraded for more than six years. ${ }^{22}$ Learning from the Philippines as a ASEAN member state, which turned around its aviation safety, must also be considered.

\section{Homework and Consecutive Acts from the Indonesian Government}

The Indonesian Aviation Law of 2009: Keeping the legal framework up-to-date

In response to consecutive aircraft accidents in Indonesia, Presidential Decree No. 3 was issued in $2007 .{ }^{23}$ A national evaluation team (Tim Nasional Evaluasi Keselamatan dan Keamanan Transportasi), which consists of seven experts, was set up for evaluating transportation safety and the security situation in the country. A three month working period was set up, which was later extended another six months considering the workload. ${ }^{24}$ This team came up with several important findings, such as i.) the authorities poor response and investigation towards aircraft accidents; ii.) unreadiness of new airlines following market liberalization and de-

21 CNN (2015). FAA Downgrades Thailand Over Aviation Safety Concerns. Available from: http://edition.cnn com/2015/12/02/aviation/thailand-aviation-safety-faa/ [Accessed August 28, 2016].

22 The New York Times (2015). Concerns Over Safety of Air Travel in Asia. Available from: http://www.nytimes. com/2015/02/06/travel/concerns-over-safety-of-airtravel-in-asia.html?_r=2 [Accessed August 29, 2016].

23 Indonesia. Presidential Decree No. 3 Year 2007 regarding the National Team for Evaluating Transportation Safety and Security.

24 Chappy Hakim. (2014), Op.cit., p. 71. regulation in 1998-2000, especially in making safety a priority; and iii.) a low level of human resource quality and discipline from both the regulator and operator. ${ }^{25}$ Finally, the team came up with some recommendations which are being included in current Indonesian Aviation $\mathrm{Law}^{26}$.

The new Indonesian Aviation Law was introduced in 2009, precisely two years after a comprehensive evaluation towards the Indonesian aviation situation was made by the team following FAA and EASA 'sanctions' following ICAO findings. Clearly the law is a response to these developments and also to update the legal framework considering the previous Indonesian aviation law was enacted in 1992.

Under the Indonesian Aviation Law, certification and licensing towards any personnel working in the aviation sector, such as those in airline operation, aircraft maintenance, airport services, and air navigation service, is mandatory. ${ }^{27}$ Thus the human resource aspect is being put more into consideration, and extended into management where the directors must have a knowledge of managerial and operational technical issues within the airline business. ${ }^{28}$

In response to market liberalization and deregulation which mushroomed the number of Indonesian airlines in the beginning of 2000 , a rule has been established that commercial scheduled airlines must own a minimum of five aircraft and possess a minimum of an additional five aircraft. ${ }^{29}$ This benchmark is aimed at ensuring aviation safety by

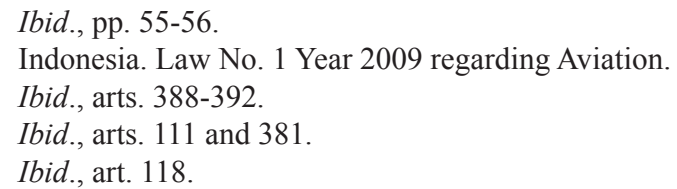


limiting airlines, so that only those with sufficient capital and sufficient aviation management capability can operate in Indonesia.

Additionally, air navigation service in Indonesia must be conducted by only one institution, which was previously done by three until 2013. ${ }^{30}$ Also NTSC professionalism must be ensured by establishing standards within a maximum of two years after the law was enacted and guaranteeing their independence by placing them directly under the President of Indonesia's supervision. ${ }^{31}$ Not to be forgotten, an aviation ethics special court will also be set up in order to ensure professionalism and avoid prosecution in a criminal court. ${ }^{32}$ Learning from Captain Marwoto in the flight GA-200 case, this special court is important for aircraft accident investigation, so that pilot and co-pilot can reveal the full truth without the worry of being prosecuted.

Finally, there is a safeguard for whistleblowers who reports a situation which does not comply with safety standards where their protection is guaranteed under the law. ${ }^{33}$ Hopefully this could prevent another Batavia Air fuel case in 2005 from happening, where $96.46 \%$ water, thus only $3.54 \%$ fuel, was found within the Boeing 737-200 (PK-YTR) during an investigation. Stricter administrative sanctions, fines and/or imprisonment are waiting for those who fail to comply; with the parties being given three years to comply with the law. ${ }^{34}$ In this case, it is better late than never.

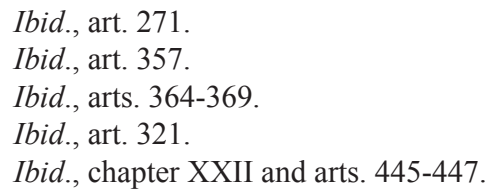

Ensuring legal enforcement and implementation: Urgency for quality Supervision from DGCA inspectors

Law enforcement has been a consistent problem in Indonesia for many years. This problem must be traced back many years before the reformation happened in 1999 when corruption, collusion, and nepotism were the rule. A mentality of "do things only as long my boss is happy" ${ }^{35}$ had lived within the public sector for a long time and even through reform the situation is improving, this mentality remains. This situation has prevented the implementation of Good Corporate Governance ${ }^{36}$ which leads to unprofessionalism of authorities, in this case with the DGCA. Thus, there is the possibility for bribery. Four examples of legal enforcement issues will be examined below.

The case of Adam Air's consecutive accidents

It was the Tambolaka incident when a Boeing 737-300 operated by the airline en-route from Jakarta to Makassar, was lost during its flight; then landed after three hours flying without direction at a small Tambolaka airport with a runway not adequate for this type of aircraft. ${ }^{37}$ According to national regulations, the aircraft should have been grounded until the NTSC investigators had finished examining this accident. However,

\footnotetext{
35 Known in the Indonesian language as "asal bapak senang". It is a well-known term for giving good news and hiding problems to the boss or superior.

36 A concept to improve corporate and government institutions management, promoting values as accountability, transparancy, transparancy, responsibility, and fairness. See Komite Nasional Kebijakan Governance (2015). Good Corporate Governance. Available from: http://knkg-indonesia.com/home/news/95-good-corporate-governance.html [Accessed August 30, 2016].

37 Chappy Hakim. (2014), Op.cit., pp. 34-35.
} 
before they arrived, Adam Air technicians came and repaired the aircraft quickly, then got a clearance permit for take-off; meaning the cockpit voice recorder and flight data recorder was erased preventing further examination. ${ }^{38}$ Thus the NTSC failed to find out the main cause, which ultimately led to the fatal Adam Air K1-574 accident a year later.

Widespread speculation was as to whether the fact that some DGCA personnel were on the payroll of the airline as well was the reason for this 'miracle' which prevented the airline from being banned or heavily sanctioned after the Tambolaka incident in 2006. At that time, one of the DGCA inspectors was simultaneously employed by Adam Air as a pilot. ${ }^{39}$ Who issued the takeoff clearance and approved its flight plan is still a mystery. ${ }^{40}$ The Tambolaka incident has strengthened the premise to prevent conflict of interest within legal enforcement, and also has shown the lack of Indonesian Air Traffic Controller (ATC) quality which failed to monitor the aircraft.

Still with Adam Air, it was strange to notice the airline's history where surprisingly afterwards the Adam Air KI-574 accident in 2007, which crashed into Makassar Strait and took ninety-six victims, the airline safety level was actually promoted from $3^{\text {rd }}$ category to $2^{\text {nd }}$ category; not the other way around or even banned. ${ }^{41}$ At the end, Adam Air's license was revoked after another accident in Batam, namely a skidding, in March 2008; when the DGCA 'finally' found that airline safety procedure and operation had

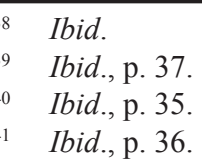

breached the national standards. ${ }^{42}$ Adam Air is a good lesson in regards to the urgency for professional DGCA inspectors.

\section{The Garuda Indonesia Flight GA-200 acci-} dent: Lack of airport safety equipment and standards

Still around the year 2007, Garuda Indonesia GA-200 which served the Jakarta-Yogyakarta route crashed while landing at Adisutjipto Airport, killing twenty-two people on board. According to the final investigation report conducted by the NTSC, the accident was purely caused by human error where the aircraft landed faster than the required landing speed; also the pilot had ignored the co-pilot's warning to go around. ${ }^{43}$

However, the NTSC also commented on the lack of equipment for rescue operations at Adisutjipto Airport when the firefighter trucks were unable to reach the unfortunate aircraft due to terrain difficulties and some did not have appropriate fire suppressants. ${ }^{44}$ Furthermore, the usage of water instead of extinguisher foam by some firefighter trucks which finally reached the location actually enlarged the fire, thus killing more people on board which were probably still alive and struggling to save themselves. ${ }^{45} \mathrm{At}$ the end, they concluded the airport emergency plan and its implementation were not held effectively, reducing the chance to save more lives during the accident.

The NTSC had recommended PT. Angkasa Pura I, as the airport operator, to

\footnotetext{
$42 \quad$ Ibid., pp. 36-37.

43 The National Transportation Safety Committee of Indonesia. (22 October 2007). Media Release No. KNKT/07.06/07.02.35.

44 Ibid.

45 Ibid.
} 
evaluate and fix its airport emergency plan; which was done accordingly and quickly by the latter. ${ }^{46}$ Again, if only DGCA inspectors could had taken the initiative inspecting the airport with its safety facilities periodically, probably more lives could be saved.

Another situation must also be highlighted, that at that time the Yogyakarta Adisutjipto did not have a Runway End Safety Area (RESA) for overshot landings installed due terrain consideration, namely river banks on both sides of the runway. ${ }^{47}$ If the airport and its runways could already be constructed on sea or artificial islands, there is no reason for not constructing a RESA in the airport. This example could explain why the Indonesian aerodrome score is lagging behind ICAO standards.

\section{The pioneer routes situation in Papua ${ }^{48}$}

The situation in Papua could become an example how legal enforcement within the Indonesian aviation world can be limited. Probably the main factor of repeated aircraft accidents in Papua is not bad weather, but it also derived from the unprofessionalism of ground crew and supporting personnel at airports. ${ }^{49}$ With high demands on pioneer

46 Hukumonline (2007). KNKT: Kecelakaan Garuda di Yogyakarta Murni Human Error. Available from: http:// www.hukumonline.com/berita/baca/hol17842/knktkecelakaan-garuda-di-yogyakarta-murni-ihuman-errori [Accessed August 19, 2016].

47 Chappy Hakim. (2009), Op.cit., p. 119.

48 In an archipelagic state like Indonesia, "pioneer routes" refers to flights connecting thousands of small islands or isolated areas which are otherwise not commercially viable. There were 217 routes classified as pioneer routes in 2015; which means those were subsidized by the government. See Ridha Aditya Nugraha. (2015). State Aid for Pioneer Routes Under Public Service Obligation in Indonesia: Against the Tide Within ASEAN Open Skies?. LL.M. (Adv.) Thesis at the International Institute of Air and Space Law, Universiteit Leiden.

49 Agus Pambagio. (2013). Protes Publik Penerbangan Indonesia. Jakarta: Gramedia, p. 75. flights and limited number of aircraft operating these routes, who can ensure that cargo is not overloaded through a bribe?

There are cases in some Papua airports or airfields where cargo is not weighted during the loading process, then being laid randomly within the aircraft without following standard operations. ${ }^{50}$ It is suspected that numerous cargo masters in small airports or airfields serving pioneer routes in Papua are not properly trained and moreover are not certified..$^{51}$ Another interesting problem from pioneer flights in Papua is regarding piloting of aircraft; where there was a case of an aircraft flown by a mechanic. ${ }^{52}$ This situation is predictably occurring due to lack of pilots within these routes. ${ }^{53}$

From an aviation safety perspective, undoubtedly the situation in Papua is very dangerous and intolerable. However, so far these situations just continue like 'normal' without any sanction given to the airline(s) and tends to become a public secret within the airline business. Furthermore, this situation has led to two important questions: how could DGCA authorities at Papua airports or airfields do nothing and where are the DGCA inspectors during these times?

A legal framework must be followed by effective enforcement, and the DGCA has failed to do this in Papua. In response to the Papua case, ensuring legal enforcement could be accomplished by improving the number of DGCA inspectors. Of course, quality must also be kept high besides fulfilling the sufficient quantity. Thus, it is a lesson

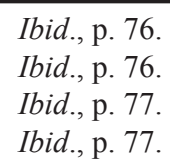


for Jakarta: do not merely talk about issuing new legislation and regulations as a solution, ensure that the human resources, especially the DGCA's and airlines' flying these pioneer routes, are adequate enough, both in quantity and quality, for proper implementation.

The Sukhoi RRJ-95B joy flight accident: Point-ing at fatal mismanagement within the air traffic service provider

The Sukhoi RRJ-95B joy flight accident that crashed into Mount Salak in May 2012 was further proof that there is something wrong with legal implementation; where the current human resource and management turned out not adequate enough to perform their duties. The situation at that time was described from by an NTSC official report on Sukhoi RRJ95B accident, which is as follows: ${ }^{54}$

"The Jakarta Approach Controller was not concerned about the limits of the Atang Sanjaya (Bogor Area) which are from ground level up to 6,000 feet. The Jakarta Approach Controller assumed that a military aircraft was eligible to fly in this area. As a result, Jakarta Approach Controller approved the aircraft to descend to 6,000 feet."

"During that period the controller was handling thirteen other aircraft. The intensive exchange of communications required the controller to transfer his attention quickly from one aircraft to another. The quick transfer of attention might have led the controller to concentrate only on the aircraft being communicated with... This situation was one of the factors that may have contributed to the Jakarta Approach controller not noticing that the Suk-

54 The National Transportation Safety Committee of Indonesia. (2012). Aircraft Accident Investigation Report No. KNKT.12.05.09.04, p. 46. hoi aircraft had disappeared from the radar screen for a period of about 24 minutes."

During NTSC interview, the controller expressed that he felt over-loaded monitoring aircraft movements. ${ }^{55}$ At that time there was no assistant or supervisor as should be, mandated in Advisory Circular (AC) 69-01, so the controller also had to cover his assistant and supervisor's obligations alone in addition to controlling the movements of fourteen aircraft. ${ }^{56}$ On paper, PT. Angkasa Pura II, as the Air Traffic Service Provider, had already enforced regulation (AC 17002) which deals with Capacity Management. However, the fact during the accident as found in the NTSC investigation report shows the regulation was not enforced properly, by having less personnel from standard.

Once again, missing action from DGCA inspectors to ensure safe operation led to another aircraft accident. If it could happen near the capital, no doubt there is a further potential this situation could occur in other parts across the country. The wellknown Indonesian public observer, Agus Pambagio, criticized the Ministry of Transportation and DGCA in 2015 for their slow action to improve the number of aviation inspectors considering the rapidly increasing number of aircraft operating in Indonesia.

As seen from the cases above, the urgency for high quality DGCA inspectors is real; and they must also be in sufficient number. To answer this need, the Minister of Transportation Decree No. 59 of $2015^{57}$ has

\footnotetext{
55 Ibid.

56 Ibid.

57 Indonesia. Minister of Transportation Decree No. 59 Year 2015 regarding Criteria, Tasks, and Authority of Civil Aviation Inspector.
} 
been enacted with the purpose of improving the output of DGCA inspectors for increasing aviation safety in the country. Under this decree, DGCA inspectors are classified into five categories, which are: i.) air transport inspector; ii.) airport inspector; iii.) flight safety inspector; iv.) flight navigation inspector; and v.) airworthiness and aircraft operation inspector. ${ }^{58}$ Such classification is to make them more focused on their particular job. The right man at the right place principle must be highly promoted.

Clear job descriptions and career paths are established within this decree, along with the qualifications needed and an evaluation method. Furthermore, inspectors are encouraged to develop themselves through seminars and workshops to earn promotions. A period of two years is set up for the current education, training or workshop system to comply this new minister decree. ${ }^{59}$ Finally, conflict of interest could be minimalized through a clear provision that a DGCA inspector may not supervise the airline, airport, or other related service they are working with. ${ }^{60}$ Within these difficult times, DGCA inspectors should become more proactive doing inspection while keeping their professionalism high. In order to do so, their income must also be adjusted with inflation and workload, namely to deter them from accepting bribes.

Considering these cases, it is not surprisingly if Indonesia's current score for organization are among the worst, with only 26.67 points, while the global average reaches 66.17; and also falling behind its neighbours such as Singapore and the Philippines

\footnotetext{
$58 \quad$ Ibid., art. 2.

59 Ibid., art. 117.

60 Ibid., art. 110.
}

with a score of 100 and 81.82 (see Table 1). This reality must be first admitted by the DGCA to become the basis for reforming its bureaucracy and management to improve legal enforcement.

\section{Reforming the bureaucracy and its ma- nagement}

All of the solutions above to improve aviation safety are invariably dependent on the readiness of the DGCA as the main overseer. Reform within the DGCA, and also other related institutions such as national air navigation service provider, must be made to improve its management function together with human resource quality and quantity.

The establishment of Perusahaan Umum Penyelenggara Pelayanan Navigasi Penerbangan Indonesia, also known as AirNav Indonesia in 2012 is one example of this bureaucracy reform. Under Government Regulation No. 77 Year 2012 $2^{61}$, AirNav Indonesia became the sole air navigation service provider in Indonesia. The country used to have three, which were PT. Angkasa Pura I (Persero), PT. Angkasa Pura II (Persero), and the service provider units on behalf of the Ministry of Transportation. However, the first two-institutions were deemed unable to work effectively due to overwhelming tasks, namely operating numerous airports in Indonesia. Furthermore, the ICAO audit resulted in a recommendation that Indonesia should established a specialized body to operate air navigation service. ${ }^{62}$ These were the two

\footnotetext{
61 Indonesia. Government Regulation No. 77 Year 2012 regarding the Indonesian Air Navigation Service Provider.

62 AirNav Indonesia. Sejarah. Available from: http:// www.airnavindonesia.co.id/id/page/about/type/history [Accessed September 2, 2016].
} 
main reasons behind the establishment of AirNav Indonesia.

Since 17 January 2013, or around three years late, AirNav Indonesia has taken over air navigation services previously held by the three different institutions. This is an effective way to improve aviation safety by setting up a uniformly high standard; which previously was varied due different standards and management methods within the different institutions. Currently AirNav Indonesia is a nonprofit institution responsible for both Indonesian Flight Information Regions (FIR), namely the Jakarta FIR and Ujung Pandang FIR. ${ }^{63}$ No doubt, these are pivotal steps from the Indonesian government, not only to fulfill ICAO safety standards and FAA category one, but also to establish AirNav Indonesia as the best air navigation service provider in ASEAN. Finally, this reform must be followed by promoting ATC staff as 'first class citizens', like pilots, through proper income. Otherwise, the high expectation of their professionalism is only a dream.

In regards to the DGCA and NTSC, having an effective spokesman and strengthening its communication department like the US National Transportation Safety Board (NTSB) could be considered. The public could be well-informed and kept up-to-date with recent development; namely to avoid being misled due speculations and irresponsible news and comments from unrelated parties.

Another important issue, cooperation with other organizations which have strong connection with aviation safety is needed. In the US, after the Hudson miracle, ${ }^{64}$ the 63 Ibid.

64 US Airways Flight 1549 made an unpowered emergen-
NTSB sent a bird sample to Smithsonian fowl experts for further examination. ${ }^{65}$ Thus bird strike could thus be further researched to decrease the potential of endangering aircraft. This situation is very relevant to Indonesia considering its situation in the equator which is a habitat for many kinds of birds.

\section{Current developments to improve aviation safety}

Shortly after another poor score was announced by ICAO in March 2015, the Indonesian Ministry of Transportation issued twenty-four regulations to address the safety and security issue. ${ }^{66}$ Recognition must be given towards this fast response, but still the main question is why did it take such a long time for them to issue new regulations. Another question is whether the Indonesian authority were capable of realizing they still lagged behind current regulation if the ICAO had not notified them with a poor USOAP score last March. These situations have put another big question mark towards the DGCA's capability and seriousness to ensure aviation safety.

In order to promote aviation safety, the DGCA has conducted a safety rating assessment towards airlines twice a year since June 2015; and those who fail shall be trained and

cy water landing in the Hudson River after multiple bird strikes caused both A-320 jet engines to fail on 15 January 2009. All passengers survived the accident. See The Guardian (2009). Miracle on the Hudson: 155 Survive Crash as Jets Hits River in New York. Available from: https://www.theguardian.com/world/2009/jan/16/usairways-plane-crash-lands-on-hudson [Accessed $\mathrm{Au}$ gust 28, 2016].

65 Chappy Hakim. (2009), Op.cit., p. 91.

66 Direktorat Jenderal Perhubungan Udara (2015). Garuda Indonesia Apresiasi Langkah Kemenhub Tingkatkan Keselamatan dan Keamanan Penerbangan. Available from: http://hubud.dephub.go.id/?id/news/detail/2476 [Accessed August 28, 2016]. 
its Air Operating Certificate (AOC) temporary suspended. ${ }^{67}$ This measure will also be implemented to all Indonesian airports in the future.

In response to the lack of training for aircraft inspectors, the Ministry of Transportation has drawn up a training syllabus, boosted recurrent and on-the-job training, and improved its monitoring of oversight activities. The move is line with its commitment to focus on transportation safety, as it plans to allocate twenty percent of its budget of IDR 48.5 trillion (US\$ 3.57 billion) in the 2016 state budget on improving safety aspects. ${ }^{68}$ A statement from one of the ministry's director for air transportation, "If an airline indicates a tendency toward this kind of incident [accidents], we will increase the frequency of airline inspections to more than seventy-five times a year". ${ }^{69}$

Another issue is that not every airport in Indonesia has been fenced properly; and even, many are still unfenced. Currently there are 237 airports in Indonesia, where 181 airports are operated by the Ministry of Transportation, with most of the unfenced airports being operated by the latter. ${ }^{70}$ Thus how to ensure aviation safety and security without this fundamental instrument. The Minister of Transportation however has

67 Direktorat Jenderal Perhubungan Udara (2015). Safety Rating Penerbangan Dua Kali Setahun. Available from: http://hubud.dephub.go.id/?id/news/detail/2382 [Accessed August 28, 2016].

68 The Jakarta Post (2015). Govt Finishes ICAO Recommendations on Aviation Standards. Available from: http://www.thejakartapost.com/news/2015/11/09/govtfinishes-icao-recommendations-aviation-standards. html [Accessed August 28, 2016].

69 Ibid.

70 Direktorat Jenderal Perhubungan Udara (2015). Menhub Minta Bandara yang Belum Berpagar Segera Dipasang. Available from: http://hubud.dephub.go.id/?id/ news/detail/2683 [Accessed August 29, 2016]. announced since September 2015 a program to construct airside fences on all Indonesian airport. ${ }^{71}$ Being late is better than never, however it must be asked how could the Indonesian DGCA have become so 'blind' towards such an obvious problem for so many years.

Certification is also another important issue that must be solved by increasing its standards on safety. Learning from the Merpati Nusantara Flight MZ 8968 accident in 2011, a Xi'an MA60 crashed to the sea while trying to land under low visibility and bad weather. Shortly afterwards, despite the cause of the accident which was human error due the airline's mismanagement and lack of training, ${ }^{72}$ there were heated debates regarding the purchase of this type of aircraft which had not received certification from the FAA; which is recognized as one of the finest benchmarks in terms of safety standards. This is the first type of aircraft which has operated in Indonesia without obtaining FAA certification. ${ }^{73}$ In other words, an airworthiness certification with number A066 towards this type of aircraft by the DGCA had raised serious questions in terms of the quality of the institution's implementation of safety standards. Moreover, Merpati Nusantara was operating fifteen Xi'an MA60 at that time, which means they were not flying in the safest manner.

With pressure to bring back Indonesia's aviation safety back to FAA category one, sometimes the authorities were too impulsive

\footnotetext{
71 Ibid.

72 The National Transportation Safety Committee of Indonesia. (2012). Aircraft Accident Investigation Report No. KNKT.11.05.10.94

73 Chappy Hakim. (2015). Tanah Air \& Udaraku Indonesia. Jakarta: Red \& White Publishing, p. 481.
} 
trying to fix the problem as soon as possible. For example, the recent Indonesia AirAsia QZ8501 crash has led the government to impose a new pricing structure, which includes an increase in the minimum airfare of low-cost carriers (LCCs) from 30\% to $40 \%$ of the maximum tariff with the intent of increasing the safety level through a more 'proper' income. However, there are debates whether low (promotion) fares equal poor safety maintenance; considering there are many other aspects besides funds behind poor safety. Finally, the NTSC came up with a recommendation on drafting a new minister regulation which obliged the pilot in command to report any known damage to the aircraft; which has been regulated under ICAO Annex 6 but not yet codified in Indonesia. $^{74}$

The DGCA deserves credit when they enacted the first drone regulation in this country under the Minister Regulation No. $90^{75}$ in 2015; which means ensuring that legal framework is not being left behind with recent developments. ${ }^{76}$ The mushrooming phenomenon of drones in this country has established a potential for threating aviation safety, especially around airports. As a response, a restricted space and maximum height of 150 meters for operating a drone without permit has been set up. An administrative procedure to obtain flight permits is

74 Direktorat Jenderal Perhubungan Udara (2015). Rekomendasi KNKT Kepada Direktorat Jenderal Perhubungan Udara. Available from: http://hubud.dephub. go.id/?id/news/detail/2775 [Accessed August 28, 2016].

75 Indonesia. Minister of Transportation Regulation No. 90 Year 2015 regarding Unmanned Aerial Vehicle within the Indonesian Airspace.

76 See Ridha Aditya Nugraha, Deepika Jeyakodi, and Thitipon Mahem. (2016). "Urgency for Legal Framework on Drones: Lessons for Indonesia, India, and Thailand". Indonesia Law Review, 6(2): 137-157. needed for operating drones for special purposes besides hobby and sport.

In response to numerous aircraft accidents in 2015, the DGCA had temporary suspended four routes for further NTSC investigation and reviews. ${ }^{77}$ In relation to airport equipment, the Minister Regulation No. $174^{78}$ has been enacted in 2015 which set up the maximum age of operational vehicle and ground support equipment at Indonesian airports. Two classifications are made, which are units with a maximum ten and fifteen years of age, in order to improve aviation safety. ${ }^{79}$ The Ministry of Transportation also encourages modernization of air navigation systems which is named "Top Sky”, replacing "Eurocat X" since 21 December 2015.80 Thus an advanced system has been installed within AirNav Indonesia, which complies with ICAO standards, such as having the newest flight plan format.

\section{External Jurisdiction and Institutional Intervention: A Helping Hand for Im- proving Aviation Safety}

Within the last decades, the aviation industry has changed drastically since it was first introduced almost a century ago. Inventions and rapid development of aviation technology has resulted in aircraft which can be

\footnotetext{
77 Direktorat Jenderal Perhubungan Udara (2016). Catatan Penanganan Masalah Penerbangan Selama Tahun 2015. Available from: http://hubud.dephub.go.id/?id/ news/detail/2809 [Accessed August 28, 2016].

78 Indonesia. Minister of Transportation Regulation No. 174 Year 2015 regarding Maximum Age of Ground Service Equipment and Operational Vehicles for Air Transport.

79 Ibid., arts. 2-3.

80 Direktorat Jenderal Perhubungan Udara (2016). Dorong Modernisasi Sistem Navigasi Penerbangan, Sistem Top Sky di MATCS Diresmikan. Available from: http:// hubud.dephub.go.id/?id/news/detail/2821 [Accessed August 28, 2016].
} 
used globally, where operating aircraft is not limited to a few as in the beginning. Within the globalized world, flying between US cities is as easy as flying between Indonesian cities, where nationalities have not become barrier to travel. Without doubt, aviation is a global issue.

Considering the current situation, EASA's assistance in improving the level of aviation safety in ASEAN not only protects ASEAN nationals; but it further protects EU nationals flying in ASEAN or with its member states' airlines. The International Air Transport Association (IATA), as a (commercial) airline association which represents 260 airlines or $83 \%$ of total air traffic, ${ }^{81}$ also has an interest to keep the airline business running and growing well. Unsafe situations shall lead to disasters where insurance premiums will spike and potential passengers shift to other forms of transportation.

\section{The European Aviation Safety Agency}

EASA plays a role in ASEAN member countries through its ASEAN Air Transport Integration Project (AATIP) supporting the creation of an ASEAN Single Aviation Market. The EU organization works together with ASEAN member states, including Indonesia and Thailand, in order to improve and harmonize the aviation safety and security standards with a budget of EUR 4,700,000. ${ }^{82}$ EASA actively supports the DGCA by organizing technical activities and setting up working groups for the development of le-

81 IATA. Available from: http://www.iata.org/about/Pages/index.aspx [Accessed August 29, 2016].

82 European Aviation Safety Agency (2015). ASEAN Air Transport Integration Project. Available from: https:// www.easa.europa.eu/easa-and-you/internationalcooperation/technical-cooperation-projects/aatipasean-air-transport [Accessed August 29, 2016]. gal framework based on EU rules; where the Technical Cooperation Activities are being held for four years, starting from October 2012 to October $2016 .{ }^{83}$ Aviation safety issues covered six activities or $36 \%$ of the approved work plan for the second year implementation phase. ${ }^{84}$

As Garuda Indonesia flies to two points in Europe (Amsterdam and London), the Indonesian authority could not 'reject' EASA's AATIP cooperation program. Moreover, the Indonesian government would not allow its flag carrier to be banned from flying to Europe for a second time. On the other hand, the EU wants to protect its citizens more while traveling abroad, in this instance while flying Indonesian airlines; especially on the Indonesian domestic routes. Thus this program could be seen as a win-win solution and an opportunity for a better aviation safety standard in Indonesia and other ASEAN member states.

However, there is a huge barrier that potentially could limit EASA's efforts. It is known as sovereignty of a state. Under this premise, the Indonesian authorities could reject or halt any program in progress. This situation reflects the strong relationship between law and politics, where the Indonesian government's political will to improve aviation safety shall be the main answer towards the effectivity of external 'interventions'.

In Thailand, the AATIP provided an assessment "EASA Part 145" of a Thai op-

83 European Aviation Safety Agency (2015). ASEAN Air Transport Integration Project. Available from: https:// www.easa.europa.eu/easa-and-you/internationalcooperation/technical-cooperation-projects/aatipasean-air-transport [Accessed August 29, 2016].

84 European Aviation Safety Agency (June 2014). ASEAN Air Transport Integration Project Newsletter Issue 1, p. 2. 
erator in Bangkok to highlight the efforts to satisfy European standards in December $2015 .{ }^{85}$ This is a relief considering the country's current downgraded aviation safety level. Meanwhile on the ASEAN level, the ASEAN Aviation Regulatory Monitoring System (AARMS) work group met in August 2015 in order to prepare AARMS to become fully operational by May $2016 .{ }^{86} \mathrm{~A}$ positive development, not only for Thai passengers, but for international passengers as well.

\section{The IATA Operational Safety Audit Pro- gram}

Considering the recent growth of Indonesian aviation market, promoting Indonesian airlines to participate in the IATA Operational Safety Audit (IOSA) program could become the solution. This program is aimed at improving the operational management and control systems of its member airlines for encouraging aviation safety. The total accident rate for IOSA carriers between 2011 and 2015 was 3.3 times lower than the rate for non-IOSA operators. ${ }^{87}$ Such a record should be of notice to the DGCA seeking to reduce aircraft accidents in Indonesia.

Currently it is only the flag carrier, Garuda Indonesia, who participates in this program. A commercial incentive from the government towards the other big airlines, such as Lion Air and Sriwijaya Air to participate

85 European Aviation Safety Agency (February 2016). ASEAN Air Transport Integration Project Newsletter Issue 4, p. 2.

86 European Aviation Safety Agency (October 2015). ASEAN Air Transport Integration Project Newsletter Issue 3, p. 2.

87 IATA. IATA Operational Safety Audit (IOSA). Available from: http://www.iata.org/whatwedo/safety/audit/iosa/ Pages/index.aspx [Accessed August 30, 2016]. in the IOSA program could be considered; considering in 2015 both airlines held a market share of around $52 \%$ of domestic flights, carrying around thirty-five million passengers throughout Indonesia. ${ }^{88}$ As of March 2015,145 of 405 airlines on the IOSA registry were non-IATA member airlines; ${ }^{89}$ thus it opens the door for these two Indonesian airlines to join. ${ }^{90}$ Establishing cooperation with the IATA means protecting passengers more by reducing the potential for aircraft accidents.

\section{CONCLUSION}

The urgency to improve the country's aviation safety level is real and necessary if Indonesia wants to continue to be recognized as an equal in international aviation. The Indonesian Aviation Law of 2009 was enacted to answer this dilemma, but in practice progress has been hindered by issues such as lack of legal enforcement, bureaucratic mismanagement, and insufficient human resources within the DGCA, airlines, airports, air navigation services, and other stakeholders. As a result, numerous aircraft accidents and incidents, many with high fatalities,

88 Jakarta Globe (2014). Lion Loses Market Share as Air Travel Growth Slows. Available from: http://jakartaglobe.beritasatu.com/business/lion-loses-marketshare-air-travel-growth-slows/ [Accessed August 30, 2016]. See also Direktorat Jenderal Perhubungan Udara (2016). Tahun 2015, Jumlah Penumpang Udara Mencapai 82,5 Juta Orang. Available from: http://hubud. dephub.go.id/?id/news/detail/2829 [Accessed August 30, 2016].

89 IATA. IATA Operational Safety Audit (IOSA). Available from: http://www.iata.org/whatwedo/safety/audit/iosa/ Pages/index.aspx [Accessed August 30, 2016].

90 The IOSA Standards and Recommended Practices (ISARPs) are applicable only to an operator that operates a minimum (i.e. one or more) two-pilot, multiengine aircraft that have a maximum certificated takeoff mass in excess of $5,700 \mathrm{~kg}(12,566 \mathrm{lb})$ for the conduct of i) commercial passengers flight with or without cabin crew; and ii) commercial cargo flights with or without the carriage of supernumeraries or cargo attendants. 
have continued during the last decade. Unfortunately, it seems that Indonesian aviation safety level has not improved that much, thus raising questions whether the government really has the willingness to take on this task. Their poor progress could also be further interpreted as actively infringing on human rights, namely failure to protect the right to life.

The cases above have shown that human resource quality and quantity in Indonesia is not adequate with the rapid growth of aviation business. Bureaucracy reform is needed with a long-term goal of improving the Indonesian human resources and ensuring legal enforcement. One of the most important aspects to achieve this goal, without underestimating other staff roles, is improving DGCA inspectors' functions through clear obligations mandated by law. At the ASEAN level, currently Thailand shares the same story as Indonesia where their aviation safety level is being downgraded by the ICAO.

Finally, legal framework is a product of political consensus, and in terms of aviation safety, Indonesia will not seriously improve without the Indonesian government's strong political will. Otherwise, all discussion of airline safety will remain just lip service. At the very least an accident free record until the end of 2017 could become a new starting point for proving that legal enforcement together with political will has been realized.

\section{Acknowledgement}

The author wishes to thank the Indonesia Endowment Fund for Education (Lembaga Pengelola Dana Pendidikan) - the Indonesian
Ministry of Finance, the Republic of Indonesia for its scholarship and funding support for this research; and to Ms. Lalin Kovudhikulrungsri from the Faculty of Law at Thammasat University for her generous support.

\section{BIBLIOGRAPHY}

Agus Pambagio. (2013). Protes Publik Penerbangan Indonesia. Jakarta: Gramedia.

Airbus (2013). Lion Air Orders 234 A320 Family Aircraft. Available from: http:// www.airbus.com/presscentre/pressreleases/press-release-detail/detail/lionair-orders-234-a320-family-aircraft/. [Accessed August on 24, 2016].

AirNav Indonesia. Sejarah. Available from: http://www.airnavindonesia.co.id/id/ page/about/type/history. [Accessed on September 2, 2016].

Aviation Safety Network (2016). Accident Description. Available from: http:// aviation-safety.net/database/record. php?id $=20160404-0$. [Accessed on August 18, 2016].

Bangkok Post (2015). Thai Airlines Pass EU Safety Test. Available from: http:// www.bangkokpost.com/learning/ work/791829/thai-airlines-pass-eusafety-test [Accessed on August 28, 2016].

Chappy Hakim. (2009). Cat Rambut Orang Yahudi. Jakarta: Kompas.

Chappy Hakim. (2010). Berdaulat di Udara. Jakarta: Kompas.

Chappy Hakim. (2014). Believe It or Not: Dunia Penerbangan Indonesia - Terbang Aman dan Nyaman Walau Banyak 
Masalah. Jakarta: Kompas.

Chappy Hakim. (2015). Tanah Air \& Udaraku Indonesia. Jakarta: Red \& White Publishing.

CNN (2015). FAA Downgrades Thailand Over Aviation Safety Concerns. Available from: http://edition.cnn. com/2015/12/02/aviation/thailandaviation-safety-faa/. [Accessed August 28, 2016].

CNN (2015). Thailand 'Red-Flagged'for Aviation Safety Concerns. Available from: http://edition.cnn.com/2015/06/19/ travel/thailand-aviation-safety. [Accessed August 27, 2016].

Direktorat Jenderal Perhubungan Udara (2015). Diharapkan Bisa Naikkan Nilai Skor Menjadi 72. Available from: http://hubud.dephub.go.id/?id/news/ detail/2466. [Accessed August 24, 2016].

Direktorat Jenderal Perhubungan Udara (2015). Garuda Indonesia Apresiasi Langkah Kemenhub Tingkatkan Keselamatan dan Keamanan Penerbangan. Available from: http://hubud.dephub. go.id/?id/news/detail/2476 [Accessed August 28, 2016].

Direktorat Jenderal Perhubungan Udara (2015). Menhub Minta Bandara yang Belum Berpagar Segera Dipasang. Available from: http://hubud.dephub. go.id/?id/news/detail/2683. [Accessed August 29, 2016].

Direktorat Jenderal Perhubungan Udara (2015). Rekomendasi KNKT Kepada Direktorat Jenderal Perhubungan Udara. Available from: http://hubud. dephub.go.id/?id/news/detail/2775.
[Accessed August 28, 2016].

Direktorat Jenderal Perhubungan Udara (2015). Safety Rating Penerbangan Dua Kali Setahun. Available from: http://hubud.dephub.go.id/?id/news/ detail/2382. [Accessed August 28, 2016].

Direktorat Jenderal Perhubungan Udara (2016). Catatan Penanganan Masalah Penerbangan Selama Tahun 2015. Available from: http://hubud.dephub. go.id/?id/news/detail/2809. [Accessed August 28, 2016].

Direktorat Jenderal Perhubungan Udara (2016). Dorong Modernisasi Sistem Navigasi Penerbangan, Sistem Top Sky di MATCS Diresmikan. Available from: http://hubud.dephub.go.id/?id/ news/detail/2821. [Accessed on August 28, 2016].

Direktorat Jenderal Perhubungan Udara (2016). Tahun 2015, Jumlah Penumpang Udara Mencapai 82,5 Juta Orang. Available from: http://hubud.dephub. go.id/?id/news/detail/2829. [Accessed August 30, 2016].

European Aviation Safety Agency (June 2014). ASEAN Air Transport Integration Project Newsletter Issue 1.

European Aviation Safety Agency (October 2015). ASEAN Air Transport Integration Project Newsletter Issue 3.

European Aviation Safety Agency (February 2016). ASEAN Air Transport Integration Project Newsletter Issue 4.

European Aviation Safety Agency (2015). ASEAN Air Transport Integration Project. Available from: https://www. easa.europa.eu/easa-and-you/interna- 
tional-cooperation/technical-cooperation-projects/aatip-asean-air-transport. [Accessed August 29, 2016].

Hukumonline (2007). KNKT: Kecelakaan Garuda di Yogyakarta Murni Human Error. Available from: http://www.hukumonline.com/berita/baca/hol17842/ knkt-kecelakaan-garuda-di-yogyakarta-murni-ihuman-errori. [Accessed on August 19, 2016].

IATA. Available from: http://www.iata.org/ about/Pages/index.aspx. [Accessed on August 29, 2016]

IATA. IATA Operational Safety Audit (IOSA). Available from: http://www. iata.org/whatwedo/safety/audit/iosa/ Pages/index.aspx. [Accessed August 30, 2016].

ICAO. Safety Audit Information. Available from: http://www.icao.int/safety/Pages/USOAP-Results.aspx. [Accessed March 15, 2016 and September 12, 2016].

ICAO. USOAP Continuous Monitoring Approach. Available from: http://www. icao.int/safety/CMAForum/Pages/ default.aspx. [Accessed August 20, 2016].

Indonesia. Government Regulation No. 77 Year 2012 regarding the Indonesian Air Navigation Service Provider.

Indonesia. Law No. 1 Year 2009 regarding Aviation.

Indonesia. Minister of Transportation Decree No. 59 Year 2015 regarding Criteria, Tasks, and Authority of Civil Aviation Inspector.

Indonesia. Minister of Transportation Regulation No. 174 Year 2015 regarding
Maximum Age of Ground Service Equipment and Operational Vehicles for Air Transport.

Indonesia. Minister of Transportation Regulation No. 90 Year 2015 regarding Unmanned Aerial Vehicle within the Indonesian Airspace.

Indonesia. Presidential Decree No. 3 Year 2007 regarding the National Team for Evaluating Transportation Safety and Security.

Jakarta Globe (2014). Lion Loses Market Share as Air Travel Growth Slows. Available from: https://goo.gl/ LP2Y2T. [Accessed August 30, 2016]. Komite Nasional Kebijakan Governance (2015). Good Corporate Governance. Available from: http://knkg-indonesia. com/home/news/95-good-corporategovernance.html. [Accessed August 30, 2016].

Kompas.com (2015). Menhub Jonan Ungkap Pesawat AirAsia QZ8501 Alami "Stall". Available from: https://goo. gl/2EJ7ES. [Accessed August 18, 2016].

Ridha Aditya Nugraha. (2015). State Aid for Pioneer Routes Under Public Service Obligation in Indonesia: Against the Tide Within ASEAN Open Skies?. LL.M. (Adv.) Thesis at the International Institute of Air and Space Law, Universiteit Leiden.

Ridha Aditya Nugraha, Deepika Jeyakodi, and Thitipon Mahem. (2016). "Urgency for Legal Framework on Drones: Lessons for Indonesia, India, and Thailand". Indonesia Law Review, 6(2): 137-157. 
The Guardian (2009). Miracle on the Hudson: 155 Survive Crash as Jets Hits River in New York. Available from: https://www.theguardian.com/ world/2009/jan/16/us-airways-planecrash-lands-on-hudson. [Accessed on August 28, 2016].

The Jakarta Post (2015). Govt Finishes ICAO Recommendations on Aviation Standards. Available from: http://www. thejakartapost.com/news/2015/11/09/ govt-finishes-icao-recommendationsaviation-standards.html. [Accessed on August 28, 2016].

The Japan Times. Japan Temporarily Lifts Flight Ban Imposed on Thai Airlines Over Safety Issues. Available from: https://goo.gl/Owc9pk. [Accessed on August 28, 2016].

The National Transportation Safety Committee of Indonesia. (2012). Aircraft Accident Investigation Report No.
KNKT.11.05.10.94.

The National Transportation Safety Committee of Indonesia. (2012). Aircraft Accident Investigation Report No. KNKT.12.05.09.04.

The National Transportation Safety Committee of Indonesia. (2015). Aircraft Accident Investigation Report No. KNKT.14.12.29.04.

The National Transportation Safety Committee of Indonesia. (22 October 2007). Media Release No. KNKT/07.06/07.02.35.

The New York Times (2015). Concerns Over Safety of Air Travel in Asia. Available from: http://www.nytimes. com/2015/02/06/travel/concerns-oversafety-of-air-travel-in-asia.html? $\mathrm{r}=2$. [Accessed on August 29, 2016].

The Telegraph (2015). Thailand Airlines Downgraded Over Safety Concerns. Available from: https://goo.gl/I03SCO. [Accessed on August 27, 2016]. 